消化性潰瘍の急性出血に対する保存的治療の進歩と手術適応 一とくに背景疾患を有する surgical poor risk 例について一

度応義熟大学医学部外科学教室（指導：阿部令彦教授）

$\begin{array}{lllrr}\text { 吉野 } & \text { 肇一 } & \text { 窪地 } & \text { 淳 } & \text { 熊井浩一郎 } \\ \text { 大谷 } & \text { 吉秀 } & \text { 高橋 } & \text { 孝行 } & \end{array}$

\title{
DEVELOPMENT OF CONSERVATIVE TREATMENT AND INDICATION OF OPERATION FOR ACUTE BLEEDING FROM PEPTIC ULCER WITH REFERENCE TO PATIENT WITH SEVERE COMPLICATION
}

\author{
Keiichi YOSHINO, Kiyoshi KUBOCHI, Koichiro KUMAI, \\ Yoshihide OTANI and Takayuki TAKAHASHI \\ Department of Surgery, School of Medicine, Keio University \\ (Director : Prof. Osahiko Abe)
}

柬引用語：消化性潰痬, 急性溃缐出血, surgical poor risk 例

はじめに

吐・下血を主訴とする消化性潰瘍の急性出血に対す る治療法は, 近年, $\mathrm{H}_{2}$ 受容体拮抗剤を始めとする強力 な薬剤の登場一消化性潰癔の一般的治㞠法においてと 同様一や，経内視鏡的止血方法の飛躍的な発展により 大きく変化したといえよう，このような急性出血例で は他に重篤な背景疾患を有する例が多いことも最近, 目立つよらである。その原因としては次の事柄を考兄 ることができる. $\mathrm{H}_{2}$ 受容体拮抗剤などにより慢性消化 性謴場のコントロールが著しく向上し, 慢性消化性潰 瘍からの単純な急性の大量出血が减少したと思われる こと，他の重篤な疾患による surgical poor riskない し critical case が人工呼吸器, 血液透析などの発展に より延命が可能になり，いわゆる stress ulcer の発生 し易い状態にある患者の増加などである。このような 例では可能な限り緊急手術を, できれば手術そのすの を回避したい.われわれは各種の保存的治療法により， この点に関しほほ满足すべき成績を上げえたと考えて いるので，時代的な变遷を踏まえて述べてみたい。

\footnotetext{
第25回日消外会総会シンポ I：消化性漬癔保存的治 療の進歩之手術適応

$<1985$ 年 5 月 15 日受理 $>$ 別刷請求先：吉野 緊一

$\overline{\mathbf{T}} 160$ 新宿区信瀑町 35 慶応義熱大学医学部外科
}

\section{対象}

保存的治療を積極的に行い始めた1976年 5 月より 1983年12月までの 7 年 7 カ月間に教室で経験した潰瑒 性病変の急性出血例104例が対象である.出血源の内訳 は表 1 のごくで, 内視鏡的に, 急性病変が約 7 割を 占めた，急性，慢性病変を合わせると胃・十二指腸潰 瘍が約 8 割を占め, 次いで胃びらん $15.4 \%$, 吻合部潰 瘍6.7\%であった。これらの内訳についての時代的な变 遷は明らかではなかった。

\section{成 繶}

1. 治療方法の時代的变遷と成績

表 2 のごとく対象を 3 期に分けて検討した. $\mathrm{H}_{2}$ 受容 体拮抗剤を使用する前の1980年 5 月までの 4 年 1 カ月 を前期， $\mathrm{H}_{2}$ 受容体拮抗剤を使用するようになった 1982 年 3 月までの 1 年 10 力を中期, さらにレーザー照射 や局注などの積極的な経内視鏡的止血操作を導入した 1 年 9 カ月を後期とした.

表 1 出血源の内訳

\begin{tabular}{|c|c|c|}
\hline 接变 $730.2 \%)$ & 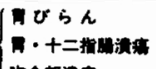 & $\begin{array}{l}16(15.4) \\
53(51.0)\end{array}$ \\
\hline 恢性票 & 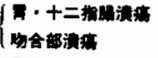 & $\begin{array}{r}28(26.9) \\
3(2.9)\end{array}$ \\
\hline $\begin{array}{l}104010 \%) \\
(100 \%)\end{array}$ & & $\begin{array}{r}104(100) \\
9\end{array}$ \\
\hline
\end{tabular}


表 2 治療方法と成績, 時期的な比較

\begin{tabular}{|c|c|c|c|c|}
\hline & $\underset{196.5 \sim 1990.5}{\text { 前 }}$ & $\begin{array}{c}\text { 中 } \quad \text { 期 } \\
1920.6 \sim 1982.3 \\
\text { (シメテシン) }\end{array}$ & 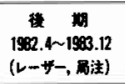 & st \\
\hline${ }_{\text {(箖严) }}$ & $20(2) \cdots 63 \% \cdots$ & $12(0) \cdots 27 \% \cdots$ & $4(0) \cdots 15 \%$ & $37(2)$ \\
\hline $\begin{array}{l}\text { 保存的治涼 } \\
\text { (出舟死) }\end{array}$ & $12(1) \cdots 37 \% \ldots$ & $33(2) \cdots 73 \% \ldots$ & $23(3) \cdots 85 \%$ & $67(6)$ \\
\hline It & $\begin{array}{c}32(3) \\
1 \\
9 \%\end{array}$ & $\underset{4 \%}{45(2)}$ & $\begin{array}{c}27(3) \\
\mid 11 \%\end{array}$ & $104(8)$ \\
\hline
\end{tabular}

保存的治療の方法は各時期により異った。前期では 抗コリン剂による薬物迷切と各種止血剂の胃内注入を 主として行った. $\mathrm{H}_{2}$ 受容体拮抗剤を使い始めた中期で は，上部消化管出血を疑った時点で直ちに cimetidine (Tagamet ${ }^{\circledR}$ ，スミスクライン, 藤沢 $\mathrm{KK}$ )を $400 \mathrm{mg}$ i. v., 以後毎 6 時間に cimetidine を200mgずつ i.v: を行 うと同時に, 治療開始時より插入してある胃管を通し て水酸化アルミニウムゲル, 水酸化マグネシウム (Maalox ${ }^{\circledR}$ ，山之内製薬 $\mathrm{KK}$ ) $30 \mathrm{ml}$ を注入し，胃管を 30 分間閉鎖, その後 30 分間開放し, 再び $30 \mathrm{ml}$ 注入とい ら手技を繰り返した。胃管を通して採取される胃内容 が $\mathrm{pH} 4$ 以上に保持されるよう,リトマス紙を用いて チェックした。 $\mathrm{pH} 4$ 以上の維持が困難な例では cimetidine の投与を毎 4 時間と増量し, 水酸化アルミ ニウムゲル, 水酸化マグネシウムの使用量も増加した。 後期ではさらに経内視鏡的止血操作一レーザー照射， 局注一を用いた。レーザー照射はNd-YAG レーザー 発振装置 (Pentax SLY-1, 旭光学 KK) を用いて 50 60 $\mathrm{W}, 0.5 \sim 1.0$ 秒の照射を反復して行った. 局注法は浅 木らの方法1)飞従い，主に純了ルコールを用いた。

さて表 2 の治療成績に戻るが，死亡例はいずれの時 期でも 4 - 11\%と有意の差は認められなかった. しか 乙保存的治療の占めた割合は前期では半数以下の $37 \%$ であったのに，中期で $73 \%$ ，後期で $85 \%$ と激増した。

そこで各時期における症例のうち，他に重篤な背景 疾患を認める症例の占める割合を検討した(表 3 )。ど の時期も背景疾患を認めた例が60～70\%前後を占め,

表 3 他に重篤な背景疾患の有無, 時期的な比較

\begin{tabular}{|c|c|c|c|c|}
\hline 当 & $\underset{1976.5 \sim 1960.5}{\text { 曹 }}$ & 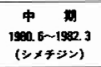 & 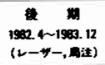 & t \\
\hline EDt & $\begin{array}{r}2291 \\
(6966)\end{array}$ & $\begin{array}{l}33 \\
\text { (73) }\end{array}$ & $\begin{array}{c}17 \\
183)\end{array}$ & $\begin{array}{c}n 2 \\
(69)\end{array}$ \\
\hline ロめ5 & $\begin{array}{c}10 \\
\text { (31) }\end{array}$ & $\begin{array}{c}12 \\
(27)\end{array}$ & $\begin{array}{l}10 \\
\text { (37) }\end{array}$ & $\begin{array}{c}32 \\
\text { (31) }\end{array}$ \\
\hline if & $\begin{array}{c}32 \\
(100)\end{array}$ & $\begin{array}{c}45 \\
(100)\end{array}$ & $\begin{array}{c}27 \\
(100)\end{array}$ & $\begin{array}{c}104 \\
(100)\end{array}$ \\
\hline
\end{tabular}

時期による差は明らかではなかった。

\section{2. 背景疾患の内訳（表 4)}

内訳の時期的な差は明らかではなかった。手術直後 の状態と悪性腫湯が最も多かった。手術直後の例の手 術の内訳は消化器の手術と消化器以外の手術がほぼ半 分していた。 悪性腫瘍の例では末期の状態がほとんで あった。

3. 手術の時期と術後合併症

このように保存的治療の成績が向上すると手術療法 への切り替えのタイミングがますます難しくなる．手 術へのタイミングを検討するために手術の時期と術後 合併症の関連性について追求した。背景疾患を認めな かった例では手術の時期に関係なく良好な手術成續で あったので，背景疾患を認めた例についてのみ検討し た（図 1).なおこれらの例は何らかの保存的治療で いったん止血し，その後ひき続いて保存的治療が試み られた例で，なかにはその期間が 1 日以内と短い例も あった. 図 1 のごとく 3 日以内, 3 回の大量出血発作 で区切ると，その枠外では合併症が $46 \%$ と倍增し，死 亡例す 1 例認めた。 なお大量出血発作とはその出血に より循環動態に変化があり, 輸血を必要とするような

表 4 重篤な背景疾患の内訳

\begin{tabular}{|c|c|}
\hline 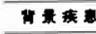 & 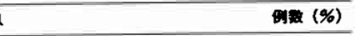 \\
\hline 手亩 & 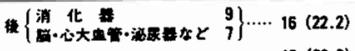 \\
\hline 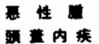 & 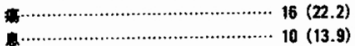 \\
\hline i・大典管斯 & $\ldots \ldots$ (12.5) \\
\hline 脑果 & (6.9) \\
\hline 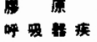 & $\begin{array}{l}1 \\
1\end{array}$ \\
\hline 不 & 金 \\
\hline 斯 理 & 要 \\
\hline 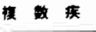 & (9.7) \\
\hline it & $72(100)$ \\
\hline
\end{tabular}

目 1 手術の時期と術後合併症, 背景疾患を伴ら例

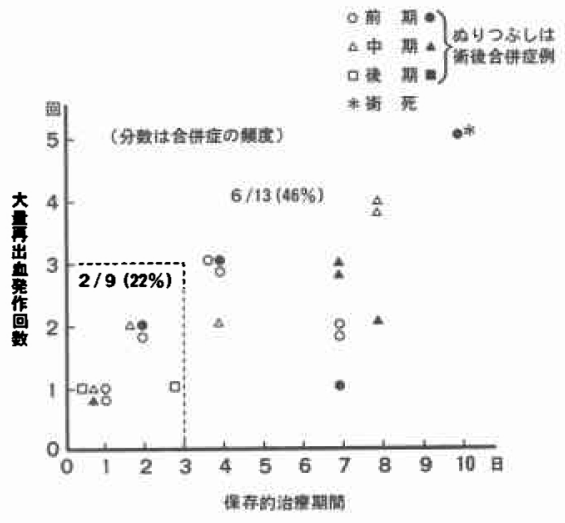


表 5 手術術式, 背景疾患と術後合併症

\begin{tabular}{|c|c|c|c|c|c|c|}
\hline 整 式 & & 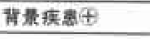 & & 散罢; & 疾息 $\theta$ & \\
\hline & & [肺合併鿊 & $3\left(1^{*}\right)$ & & & \\
\hline 広 切 & 9例 & 需不全·䀢水秘 & 1 & 6例 & & \\
\hline & & 心不全 & 1 & $\Rightarrow$ & 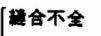 & 1 \\
\hline & & 残用出血 & 1 & & 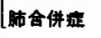 & 1 \\
\hline \multirow{3}{*}{ 周垔全墒 } & & | 合不全 & 1 & & & \\
\hline & $\Rightarrow$ & 心不全 & 1 & 2例 & & \\
\hline & & 畘不全 & 1 & & & \\
\hline 同全描 & 5例 $\Rightarrow$ & $\Rightarrow$ 帽合併症 & 1 & 1 例 & & \\
\hline \multirow[t]{2}{*}{ 罱切十迷切 } & S例 & [MOF & $1\left(1^{*}\right)$ & & & \\
\hline & $\Rightarrow$ & 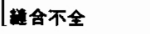 & 1 & & & \\
\hline \multirow{2}{*}{$\begin{array}{cc}\text { * } & \text { の 他 } \\
\text { 尌 } & \\
\end{array}$} & 3例与 & $\Rightarrow$ 出 血 & 1 & & & ・曹 \\
\hline & 28例 & & $13(46 \%)$ & 99:- & & $2(22 \%)$ \\
\hline
\end{tabular}

出血とした。

4. 手術術式, 背景疾患と合併症（表 5 ）

手術を施行した37例について検討した。行われた術 式は広範囲胃切除 (広胃切) が最も多く, 胃亜全摘, 胃全摘，胃切十迷切などがこれに次いだ．表 5 で下欄 の“その他”とは胃切開などによる出血部の単純絴合 止血である，全体をみて，とくにどの術式が良い成績 をむたらせたとはい壳ない。

\section{考察}

以前よりわれわれは急性上部消化管出血に対しては 積極的に内視鏡検査を行ってきた2). また1976年より は保存的治療に力を入れている. その間, $\mathrm{H}_{2}$ 受容体拮 抗剂, 経内視鏡的止血方法の飛躍的な向上なと，従来 になかった治療方法が導入され，時期的な差が明らか である.そこで 3 期に分けて検討したところ，治療方 法の主役が手術から保存的方法に変ったものの, 死亡 率からみる限りほぼ同様の成績が得られた。同じ成績 が得られるのならば保存的治療が望ましい.とくに本 成績のように, 出血例の過半数を占めた, 他に重篤な 背景疾患を有する surgical poor risk 例では保存的治 療が選択されるべきである. 対象例の出血源, 背景疾 患の有無などについて時期的な差異が明らかではな かったので保存的治療は確実に進歩したものと考えら れる。

使用薬剤として最近ではセクレチン(セクレパン, エーザイ KK） む併用している。

全時期を通じて背景疾患を有する例が圧倒的に多 かったのはわれわれの施設の特殊性にもよると思われ る.すなわち救急車などによる外来救急患者はきわめ て少なく一病床不足で受け入れられない一, 出血例の ほとんどがすでに入院していた症例であった。
背景疾患を伴5 critical な出血例では手術への決断 のタイミンクがきわめて難しい。これまで述べたよう に各種の保存的治療法が著しく進歩した現在, 保存的 治療に頼りたいといらことと，逆にこのような例では 保存的療法から手術の切り替六のタイミングのわず かな荤延が致命的な因子になってしまうという controversy 酒直する。 われわれの術後合併症の検討よ ク, いったん止血後, “3 日以内の 3 回までの大量再出 血”が保存的治療の限界といらことが，一応の目安と なると考学られる。従来の長尾らのの $1,000 \mathrm{ml}$ の急速 輸血で循環動態の安定が得られない例では手術を行ら べきといら考党はきわめて重用されてよいるのと思わ れる.しかし各種の保存的治療法が非常に発展した現 在，それらの保存的治療が，設備，人材等が整ってい て, 十分に行いらる施設では, とくに重篤な背景疾患 を有する例に対しては“3 日， 3 回”の指標も試みら れてよいと思われる. 出血例に対する緊急内視鏡検査 の技術は全身管理も含めて, 決して易しくはない。乙 かしきわめて危険性の高い手術を回避することも可能 とする方法であるので，消化器疾患を尃攻する医師は 手術などと同様に，経内視鏡的止血技術の取得に励を べきである. かつては内視鏡的飞拍動性の, すなわち 動脈性の出血が顕著に認められた例は直ちに緊急手術 の適応となったが，現在ではその上らな例む経内視鏡 的止血のよい適応となる。

手術術式に関してであるが，患者の全身状態，出血 源の病変の性状, 位置などにより選択される術式はさ まざまであり，本成績からも一概にどの術式がよいと はいえない，単純な慢性消化性潰場からの出血であれ ば，全身状態が許せば，慢性漬晧に準した術式，すな わち胃潰場では謴煬を含めて広胃切, 十二指腸潰掦で は出血点を綎合止血後, 迷走神経切離術（迷切）を主 にした術式が好ましいと思われる。急性の胃びらん (AGML)には病変部の切除, 多くの場合, 胃亜全摘が よいと思われるが，その際には迷切を付加すること， また胃西全摘でも病変が残存するような例では胃全摘 を施行すべきであると考兄ている，術後の合併症とし て残胃出血，胃出血が各 1 例隹認められ，これらはい ずれも救命し亲たすのの，手術時に出血部位を残存さ せたために生じた可能性がある. 出血時の内視鏡検查 では視野が不良であるため, 病变の見落としがあるこ と,および AGML や急性潰場は術中の視・触診によっ ては確認され難いことなどにより，術中，胃切開など により, 出血性病変の取り残しのないように努力しな 
ければならない。

$$
\text { まとめ }
$$

1. 消化性溃瘍の急性出血に対する保存的治療成績 は近年，著しく向上した。

2. 他に重第な背景疾患を伴 5 surgical poor risk 例では，保存的にいったん止血したあと，“3 日以内の 3 回の大量出量”が保存的治療の限界と思われた。

関根旨之助手を始めとする本学放射線診断部胃班諸兄の ご協力に感謝します。
文嗝

1）浅木 茂, 西村敏明, 佐藤 彰ほか：消化管出血に 対する内視鏡的止血法の止血機序とその位置つ け. Gastroenterol Endosc 26 : 2279-2284, 1984

2）吉野肇一，大柣道夫，比企能樹ほか：我々の絓験し た“外科的出血性急性胃潰場”について. 臨外 $24: 927-932,1969$

3）長尾房大, 池内準次, 首雨一影：消化管出血の病態 之部位診断。外科治䖒 $45: 495-501,1981$ 